\title{
Education and Agricultural Productivity in Democratic Republic of Congo: The Case of South-Kivu Province
}

\author{
Murhi Mihigo Isidore ${ }^{1,2}$, Mubagwa Cihinda Muko Cisabu ${ }^{2}$, Mireille Mwamini Murhebwa ${ }^{3}$ \\ ${ }^{1}$ Expertise Centre on Mining Governance, Faculty of Economics, Catholic University of Bukavu, Bukavu, Democratic Republic of Congo \\ ${ }^{2}$ Laboratory of Applied Economics for Development, Faculty of Economics, Bukavu, Democratic Republic of Congo \\ ${ }^{3}$ Higher Pedagogical Institute (ISP), School of Language Studies (SOLAS), Bukavu, Democratic Republic of Congo
}

Email address:

murhi.mihigo@ucbukavu.ac.cd (M. M. Isidore)

\section{To cite this article:}

Murhi Mihigo Isidore, Mubagwa Cihinda Muko Cisabu, Mireille Mwamini Murhebwa. Education and Agricultural Productivity in Democratic Republic of Congo: The Case of South-Kivu Province. International Journal of Elementary Education.

Vol. 7, No. 1, 2018, pp. 7-12. doi: 10.11648/j.ijeedu.20180701.12

Received: October 27, 2017; Accepted: December 7, 2017; Published: March 7, 2018

\begin{abstract}
The problem of education and agricultural productivity has widely been addressed in literature. The Agriculture sector plays a great role of survival in the planet. Many countries found their savings reach the pinnacle because they oriented their investment in agriculture and in education. The Democratic Republic of the Congo (DRC) is one of the best equipped countries in the world in terms of arable land. However, it remains a country through which the population has a limited food access. This paper shows how education impacts agricultural productivity in South-Kivu. Data used in this article are from survey conducted in November 2016 and completed in June 2017 on 210 small farmers. The main result is that when the education level increases, the tendency of people is to leave the agriculture sector. In other words, the high formal education has a negative influence on agricultural productivity.
\end{abstract}

Keywords: Education, Productivity, Agricultural and South-Kivu

\section{Introduction}

Agriculture sector plays an incontestable role in the survival of the planet. Its importance is well established. Several countries have seen their savings reach the pinnacle because their investment they oriented in agriculture [1]. The Democratic Republic of the Congo is one of the best equipped countries in the world in terms of arable lands ( 80 million hectares of arable lands are available). However, it remains a country where food addiction is the highest [2]. According to the government rapport, the food situation is precarious; 16 million of people or $33 \%$ of the population are facing serious deficits in covering their food needs [3].

This calamity has several origins: the low level of the national budget allocated in agricultural sector (less than $2 \%$ ), abandonment of the sector in hands of the farmers who produce only for subsistence, the presence of several extensives undeveloped, the lack of professionalism of the majority of stakeholders in the sector, etc.

As consequences malnutrition is increased, there is food insecurity, and frankly household's poverty. Families which are in rural areas, are the most affected because they totally depend on agriculture. [4] Often attribute the low production carried out by the majority of African farmers to lack of training, low level of education as well as lack of knowledge of the industry. For [2], traditional methods of production are the basis of low agricultural productivity in South-Kivu. The mechanization, using of fertilizers and farmer's training can be seen as a remedy. Then, in South-Kivu, education becomes a key element that can lead to a balanced output in the sector as suggested by the literature review. [5] and [6] show how the level of education has a positive influence on the adoption of new technologies in agriculture. The adoption of new technologies is one of the components of the increased agricultural productivity, which is induced by the level of education, it is important to know how education directly affects agricultural productivity. Thus, this paper tries to answer the question: Does education contribute to agricultural productivity in South-Kivu? The purpose of this study is to find the impact of schooling on agricultural productivity. We test the hypothesis, that education positively affects 
agricultural productivity in the South-Kivu. Several studies [7], [8], [9], [4] and [1] have directly addressed this issue throughout the world. The few existing studies in DRC (especially in South-Kivu) are limited to understand the effect of education in the adoption of new technologies and the description of the vulnerability phenomenon's [10] and [2].

There are several approaches to measure the effect of education on agricultural productivity [11], [7], [8], [9], [4], [12] and [1]. To measure the effect of education on agricultural productivity many authors such [11] and [4] use the Cobb-Douglas production function. This approach is adopted to estimate the impact of education on agricultural productivity in this paper. Data used in this study are from a survey conducted conducted in November 2016 and completed in June 2017 in three territories in South-Kivu province which are Kabare, Walungu and Uvira. This article is subdivided into six sections. After this introduction, the study includes the literature review, the South-Kivu agricultural context, research methodology, results and discussion and, conclusion.

\section{Literature Review}

The link between education and increasing agricultural productivity is very well documented in the literature. According to [12], agricultural productivity is measured as the ratio of agricultural output to agricultural input. Its measures are subdivided into partial, multifactor and total productivity. Partial productivity is the amount of output per unit of a particular input. It only considers a single input in the ratio. Literature indicates that it is easy to compute as it requires limited data, but it can be hard to identify factors that cause productivity of field crops to change. Both Multifactor productivity (MFP) and Total factor productivity (TFP) are defined as the ratio of the total agricultural output to a subset of agricultural inputs. Many other measures affect the agricultural productivity, such as new technologies, economies of scale, managerial skills, changes in the organization of production to agricultural production and the formers' schooling [13]. Some studies looked at the role of public investment, political stability and natural resources degradation in increasing agricultural productivity [14].

African farmers receive little support, especially when are compared to that given to many farmers in developed countries [15]. Indeed, for most of the last fifty years, farmers in Africa have been subject to a negative net rate of assistance when considering the balance between public spending and protection on one hand, and forms of explicit taxation on the other hand. Various authors support that commercial inputs like machinery and fertilizers play a role in agricultural productivity growth and can achieve sustainable food security. Investments in research, development, extension and agricultural education are reflected in a steady increase agricultural productivity [13].

In most African countries where agriculture plays an important economic role, the illiteracy rate is important. To address this weakness, countries have set up adult education programs with formal and non-formal basic education. For [1], agricultural advances of modern times, as measured by the usual growth of total factor productivity, are favored primarily by technological advances and farmers training. There are studies which address the mechanism by which education increases the level of performance in agriculture [16]. The development policies currently consider improving the quality of human resources brings workers greater productivity through raising the level of health and nutrition and especially of education. [17] Show that the accumulation of human capital, through education is the major determinant of labor productivity. Education is therefore an important asset because it makes a productive service. Education is primarily seen as an investment and the level chosen by the individual is determined through a process incorporating the innate abilities of the individual, social and economic characteristics of the family, the environment and education provisions. Education plays on efficiency through production techniques [18].

The only notion of human capital that is considered here is school education and empirical models in question are therefore situated in a tradition that treats education as a measure of the quality of labor. But that education has a role to boost productivity, it is still necessary that the question on the quality of education and institutions which ensures. Other studies estimated that it is primary education which has a direct and significant effect on agricultural productivity [19]. Literature discovers a threshold effect in farmers between one and six years of schooling are not significantly more productive than those who have never been to school, whereas those with seven or more years of schooling are more productive than those with less education. [12] Also found that at least four years of schooling are needed for education to affect farm output in Uganda. The author noted that this is commonly thought to be approximately the amount of schooling needed for literacy and numeracy to be functionally attained. For less complex techniques, education is not a relevant variable for the performance of producers. And literate peasants who do not have tools to change production techniques are more effective than the illiterate. This is why education policy must be accompanied by peasants' equipment policies or transmission of more modern techniques if they want to have more chance to increase the performance level of agricultural producers. Empirical studies [22] have already been conducted to detect the role of education in agricultural production. Other researchers [21] and [22] confirm that education has a great role in sustainable development.

\section{South Kivu Agricultural Context}

Despite its huge agro-ecological potential and work efforts by $519,636.2$ average farm households per year, the South Kivu province has been able to achieve an average agricultural production of 3,457,727 tons in 2006 all cultures. What makes agricultural production per farm household per year 6.6 tons of agricultural products all crops (food crops, 
vegetables and fruits) [20].

This failure of agricultural production in South-Kivu has caused several consequences: the resurgence of hunger and food insecurity, the impoverishment of the rural population due to low agricultural production, rural migration due to unemployment rural environment, and dependency of food from outside the country. Thus, to feed its population, the South-Kivu province has to use outside products (imports). This denotes a paradox when comparing the potentialities that abound the province and that of the population starvation due to lack of sufficient production of making food. Without sufficient agricultural production and lack of surplus for sale to local or foreign market to meet other basic needs, the South-Kivu population languishing in misery and that only worsened overnight. Several obstacles such as lack of agricultural equipment, the low educational level of farmers, the disinterestedness of youth in agriculture, the practice of farming family and the lack of professionalism, leading to the disintegration of agriculture in the province and in all the country generally. Since the early 2000 s, there was a return to subsistence farming in several isolated areas [3]. Food production is entirely conducted in small farms that cultivate less than one hectare per year on average and practicing polyculture (food, fruit, small livestock, etc.). It is an agriculture using very few external inputs. [1] Estimate that the expected results, government policy should focus on agriculture and education sectors.

Table 1. Production statistics of leguminous plants in South Kivu (in ton) from 2001 to 2012.

\begin{tabular}{|c|c|c|c|c|c|c|c|c|c|c|c|c|}
\hline \multicolumn{13}{|c|}{ Total production in ton } \\
\hline Crops & 2001 & 2002 & 2003 & 2004 & 2005 & 2006 & 2007 & 2008 & 2009 & 2010 & 2011 & 2012 \\
\hline Groundnut & 37480 & 23173 & 32786 & 20399 & 69790 & 99276 & 29847 & 15681 & 27059 & 16717 & 61385 & 94175 \\
\hline Beans & 111251 & 79292 & 74089 & 61310 & 116267 & 142059 & 84502 & 65338 & 59347 & 44523 & 93564 & 103259 \\
\hline Green pea & 1599 & 733 & 1075 & - & 294 & 1356 & 1053 & 384 & 615 & - & 139 & 821 \\
\hline Soybean & 8906 & 3744 & 4309 & 3895 & 4131 & 22904 & 4781 & 2270 & 2791 & 1968 & 2251 & 12757 \\
\hline
\end{tabular}

Source: rapports division provinciale de l'agriculture au Sud Kivu, 2001-2012

For the four underlined crops production has increased for groundnut and soybean. It decreased for beans and green pea with respectively from 111251 to 103259 tons (approximately 10 per cent) and from 1599 to 821 tons (approximately 53 per cent). Concerning groundnut and soybean, the production had passed from 37480 tons to 94175 tons, an increase of 251 percent and from 8906 to 12757 tons either an increase of 43 percent. The table shows that the agricultural production is still low comparing to the needs of the province, this can be the raison of importing food in South Kivu.

\section{Research Methodology}

In this section, methods are proposed to measure different effects of schooling upon agricultural output. The foundation of this article is an intensive literature review, document analysis of agricultural education and econometric analysis. Structured questionnaire was administered, as well as an interview conducted for the selected farmers in order to collect relevant data. Descriptive statistics, the multiple regression analysis, statistic tests such as the test of difference between means of factors were used for meeting the objectives of this study. In addition a survey was conducted in three territories in South Kivu (Kabare, Walungu and Uvira) in November 2016 and completed in June 2017. The analysis was based on a sample size of 210 farmers comprising between 39 of them with school agriculture knowledge and 171 of them without this knowledge. The responses from the informants were coded and entered into a data sheet using Stata software. The studies reviewed in this paper suggest many important hypotheses relating agricultural productivity to its determinants. Empirical works underline that the factors that can affect the productivity in agriculture are numerous [1]. Although the focus of this review is on the measurement and analysis of agricultural productivity. The model we estimate is a Cobb-Douglas production function based on agricultural productivity as the dependent variable. Agricultural productivity is measured as the ratio of agricultural outputs to agricultural inputs. The literature on the effects of education on agricultural productivity is divided into two major camps: frontier versus non-frontier (direct) methods for estimating the production function [16]. Estimation of the effects of education upon productivity using direct, non-frontier methods dates to the 1960s. Multiple regression analysis is used to determine the factors that critically influence the productivity of bean in the study areas. By choosing a CobbDouglas we assume that the relation between agricultural production and the input factors is linear in logarithms with constant returns to scale. The choice of "log" specification is based on theoretical hypotheses. In its simplest form we can thus express equation in a Cobb-Douglas production function:

$$
\operatorname{Ln}(\mathrm{Y} / \mathrm{L})=\beta 0+\beta 1 \ln \mathrm{X}_{1}+\beta 2 \ln \mathrm{X}_{2}+\ldots+\varepsilon
$$

Where $\mathrm{Y}$ is the production value, $\mathrm{L}$ is number of people employed by the farmer in the bean fields. The choice of "log" specification is based on theoretical assumptions nature. $\beta_{0}$ is the intercept of the regression, $\beta 1, \beta 2, \ldots$ are the elasticities of $\mathrm{Y}$ with respect to the independent variables respectively. $\varepsilon$ is the stochastic error term, which represents omitted, yet relevant but difficult-to-capture variables.

Explicitly, the relationship between the agricultural productivity and input variables for the functional form of production used is expressed as follows [17], [18] and [14]: 
LnAGIPRO $=\beta_{0}+\beta_{1} \ln$ EDUCFARM $+\beta_{2} \ln$ FOODAID $+\beta_{3} \operatorname{lnLA}$ $\mathrm{NDT}+\beta_{4} \ln$ ACCREDIT $+\beta_{5} \ln$ AUTREACTIV $+\beta_{6} \mathrm{NONAGRIN}$ $\mathrm{CO}+\beta_{7} \operatorname{lnFARMAGE}+\beta_{8} \operatorname{lnFARMAGESQ}+\varepsilon$

Where AGRIPRO expresses the agricultural productivity as the dependent variable,

Agricultural productivity is measured here as the ratio of agricultural outputs of beans to farm size in hectares. This variable is converted into natural logarithm to ensure normality.

The dependent variable is the natural log of the value of agricultural productivity deflated by differential between beans production than its surface area. In other words, agricultural productivity is taken as the yield of beans (metric kilogram per meter).

EDUCFARM is the education farmer. It is a categorical variable with values ranging from 1 to 4 . This variable measures the education level of the farmer in terms of years. Higher value indicate greater levels of education.

FOODAID denote Aids in food from government or other non-government organizations. It is a dummy variable whether the farmer has received aid in food or not.

LANDT is land tenure system use of agricultural implements. It measures the existing size of land owned. The variable ranges between 0 and 1, with 1 denoting that beans size land cultivated by the farmer in owned and 0 otherwise.

ACCREDIT describes access to agricultural credit by the farmer. This is a dichotomous variable assuming two values. 1 and 0 , indicating accessed and non-accessed to agricultural credit respectively.

NONAGRINCO libels non-agricultural farmer incomes and captures as dichotomous variable. A value of 1 denotes the presence of other incoming sources a part from farming. While 0 indicates the absence of other income resources.

AUTREACTIV is a dummy variable denoting whether the farmer practices other activities apart from agriculture which run concurrently with his agriculture activities or not.

EXPET expresses the number of years since the farmer practices this activity. It is quantitative variable. This variable is captured as discrete variable. $\beta_{0}$ is the constant or intercept, and $\varepsilon$ is the residual term. Residual is the different between the observed values and those predicted by the regression equation.

$\beta_{\mathrm{i}}$ are regression coefficients (elasticities). The coefficients $\beta_{\mathrm{i}}$ thus reflects the percent contribution of each independent variable on the dependent variable.

Beans production is the crop which this study examines the education influence on its productivity. Each independent variable is integrated in the model individually before constructing the final model. This regression by step helps to isolate individual effect of each independent variable on the agricultural productivity of beans. Some variables were rejected because of multicolinearity.

\section{Results and Discussion}

The socioeconomic characteristics of informants underlines that these latter were all $(100 \%)$ adults from above 25 years, however, 28 percent of the respondents are aged between 25 40 years. 71 percent of the respondents were aged between 41 years and above. These findings are synonymous with [1] that people in age groups of 45-60 in developing countries are very active in agriculture.

Our results revealed that 76 percent of the respondents are married while only 2 percent are single and 21 have another marital status. The table shows again that 51 percent of the respondents are not educated, 29 have the primary level of education, 17 reached the secondary level and only 2 percent of the informants have academic education.

The result implies that education is one of the most serious constraints against the agricultural productivity in the areas of study. Of course this goes to confirm the earlier deduction by [16]; that education acquired by farmers has a positive influence on farmers' labor and income. In South-Kivu, when people access to a high level of education, the tendency is to leave agriculture sector. When we examine the land size on which beans are cultivated, 854 square meter is the average for each farmer. Based on studies [16] in the majority of cases small farmers have less than one hectare in Africa. Tenure security is one of the factors that influence investment to enhance land productivity. Moreover, other factors than land tenure may play a bigger role in determining farmers' decisions to invest in their landholdings. These include such as farmer schooling, agro-climatic conditions, population density, farm size, presence of perennial crops on the land, access to local market. [2] Supports that family size and household composition also plays a significant role.

The tables 2 and 3 show the econometric results computed by the stata software.

Table 2. Simple regressions with agricultural productivity as a dependent variable.

\begin{tabular}{lcl}
\hline Variables & Coeff. & $\mathbf{P}>|\mathbf{t}|$ \\
\hline Education & -.045 & $0.0012^{*}$ \\
Food aid & -.234 & $0.049^{* *}$ \\
Land tenure & .283 & $0.013^{* *}$ \\
Access to agricultural credit & -.271 & $0.0020^{*}$ \\
Nonagricultural income & 3.141 & 0.201 \\
Other activities & -.359 & $0.002 *$ \\
Experience & .229 & 0.148 \\
\hline
\end{tabular}

Source: stata outputs

* significant on $1 \%$ level

** significant on $5 \%$ level

Econometric results are given by partial table 2 above. The estimated equation by education shows that Bean productivity in South-Kivu is negatively related to the education in contradiction with results from Nigeria [22]. In other words, one-year increase in education for rural people 
in South-Kivu, productivity decreased by 4.5 percent. This is explained by the abandonment of agriculture by people who are more educated. At the same time, assistance in food has a negative effect on agriculture productivity. When a farmer has received aid food, his productivity is affected by $-23.4 \%$. However, agricultural productivity is positively related to the use of owned land (28.3\%). Access to credit influences negatively the agricultural productivity (-27.1\%). This because when farmers access to credit, they vary activities in order to find possibility of reimbursement of that credit which is often for short term. Concerning the non-existence of other activity apart from agriculture, it has a very significant level on agricultural productivity. When the farmer practices only agriculture, his productivity is very higher than the one who combines with other rural activities as it is for those who have other revenue sources. Finally, experience in agriculture sector has a positive impact on agricultural productivity. The first step (table 2) was used to include only one independent variable in regression model. The second step (table 3 ) includes all the seven independent variables at the same time. Results are given below:

Table 3. Regression results with InAGRIPRO as a dependent variable.

\begin{tabular}{lll}
\hline Variables & Coefficients & $\mathbf{P}>|\mathbf{t}|$ \\
\hline Constant & 3.1874 & $.000^{*}$ \\
EDUCFARM & -0.538 & $.000^{*}$ \\
FOODAID & -0.143 & $.057^{* * *}$ \\
LANDT & 0.104 & $.066^{* * *}$ \\
ACCREDIT & -0.040 & $.001^{*}$ \\
NONAGRINCO & 2.94 & $.071^{* * *}$ \\
AUTREACTIV & -0.285 & .042 \\
EXPER & 0.514 & $.009^{*}$ \\
Number of obs $=210$ & & \\
F(7, 202) $=84.87$ & & \\
Prob $>$ F $=0.0000$ & & \\
R-squared $=0.7463$ & & \\
Adj R-squared $=0.7375$ & & \\
Root MSE $=0.807$ & & \\
\hline
\end{tabular}

Note: The regressions were estimated using robust standard errors to heteroscedasticity.

Source: survey conducted in June 2015 in three territories in South-Kivu.

After applying and running the linear Regression upon the Cobb Douglas Production Function, following results were found. As we can see (table 3), contrary to all expectations, farmer education has a negative effect upon agricultural productivity. Most small farmers who had been investigated on had non education. [18] Found that unskilled labor has a negative relationship with labor productivity. It's important to note that there are no specialization courses of agriculture in South-Kivu even for educated people. The regression analysis, revealed that land tenure and farmer experience have positive impact on bean production while, food assistance, access to credit and other activities (extra-agriculture activities) have negative influence on bean productivity in South-Kivu. [16] Reported in their work that access to agricultural credit had a positive influence on output of snail production. However, variables such as aids of food from the government or nongovernment organizations, non-agricultural farmer's incomes and other activities apart from agriculture but run concurrently with agriculture have negative influence on beans productivity. The value of the (Root MSE) indicate that Cobb-Douglas equation is a good one because it highest value (0.807) and meeting other econometric criteria. The test of difference between means for educated and uneducated underlines that, concerning the bean production, there is no significant difference between the two categories of farmers. The paradox in this result concerns the finding signs of some variables such as education and access to credit. Concerning factors which limit the positive effect of education on agricultural productivity, I can refer to several realities in the workplace. Many problems can be raised. Among those factors we noticed that most people leave agriculture sector when they reach high level of education. The sample was dominated by illiterate persons, mentioned by seven individuals, concerned the work environment and the quality of relationships among people. It is recommended that training of farmers should be privileged instead of formal education in South-Kivu as proposed in Nigeria [22].

\section{Conclusion}

The present study attempted to investigate the effect of education on agricultural productivity in RD Congo the case of South-Kivu province. Literature review and research findings indicated that education had a positive impact on agricultural production. But the majority of respondents did not consider education to be the main factor influencing agricultural productivity in South-Kivu. The data were collected in November 2016 and completed in June 2017 in three territories. Structured questionnaire was administered, and an interview was conducted to the selected small farmer's information in order to collect relevant data. Descriptive statistics, the multiple regression analysis were used to meet the objectives of this study. The socioeconomic variables indicate that 76 percent of the respondents are married while 2 percent are single and 21 have another marital status. 51 percent of the informants are not education, 30 have the primary level of education, 17 reached the secondary level and only 2 percent of the respondents have academic education. Concerning the econometric results the schooling had a negative impact on agriculture production in the area study. In South-Kivu, when people reach high level of education, the tendency is to leave agriculture sector. Also we find that education itself is not significant, but it must be accompanied by other inputs such as the land size, access to credit. Other findings are that aids in food from government or other non-government organizations, non-agricultural farmer incomes and other activity than agriculture but run concurrently with agriculture have negative influence on agriculture productivity. These findings concern small farmers. The next paper must be focused on great farmers. Overall, the findings of the present study suggest that the negative effect of education on agricultural productivity is due to the neglect of the agricultural sector, both by the State organizations and by Non-Government Organizations. To improve this productivity, stakeholders must find appropriate trainings. 


\section{Acknowledgements}

We warmly thank the Expertise Centre on Mining Governance (CEGEMI) and VLIR-UOS for facilitating the collection of additional data on the outcome of this research.

\section{References}

[1] Engler S. and Kretzer M. M., 2014, "Agriculture and Education: Agricultural Education as an Adaptation to Food Insecurity in Malawi", Universal Journal of Agricultural Research, P 224-231.

[2] Bucekuderhwa Bashige C., 2013, "Is there a possibility of technical progress for substistence farming?" Bukavu Journal of Economics and Social Sciences (BJSS), L'Harmattan, p. 148-180.

[3] Rapport de l'état des lieux de la République Démocratique du Congo sur le droit à l'alimentation, Gouvernement de la RDC (2010).

[4] Eliophotou M. M., 2010, "The link between education and productivity: the employers' perspective", International Conference On Applied Economics - ICOAE.

[5] Adéoti R., O. Coulibaly et Tamò M., 2002, Facteurs affectant l'adoption des nouvelles technologies du niébé Vigna unguiculata en Afrique de l'Ouest, Bulletin de la Recherche Agronomique du Bénin. Numéro 36.

[6] Arellanes P. and Lee D. R., 2003, "The determinants of adoption of sustainable agriculture technologies: evidence from the hillsides of Honduras", Proceedings of the $25^{\text {th }}$ International Conference of Agricultural Economists (IAAE, Cornell University, Ithaca, NY, 14853, USA.

[7] Hua P., 2005, "How does education at all levels influence productivity growth? Evidence from the Chinese provinces », CERDI, Etudes et Documents, Ec 2005.15.

[8] Pudasain Som P. 2011, "The Effects of Education in Agriculture: Evidence from Nepal", Oxford University Press on behalf of the Agricultural \& Applied Economics Association.

[9] Kausar P., 2011, "Impact of educated farmer on Agricultural Product", Journal of Public Administration and Governance ISSN 2161-7104, Vol. 1, No. 2

[10] Mufungizi Nabintu A., 2006, «Les déterminants du revenu agricole commercialisé dans les ménages ruraux du Sud-Kivu », LEAD, Projet PIC « Dynamique des filières productives et développement rural intégré », CUD, Document de travail, miméo, LEAD, UCB.

[11] Sharada Weir, 1999, "The Effects of Education on Farmer Productivity in Rural Ethiopia", Centre for the Study of African Economies.
[12] Archer A., 1981, Farmer's education, their age and the productivity of agricultural inputs according to milk farm sizes: the case of region "04", Quebec. L'Actualité économique, vol. $57, \mathrm{n}^{\circ} 1$, p. 113-127.

[13] Cervantes-Godoy, D. and J. Dewbre, 2010, "Economic Importance of Agriculture for Poverty Reduction", OECD Food, Agriculture and Fisheries Working Papers, No. 23, OECD Publishing.

[14] Eason Ashley N., 2014, "Secondary school agricultural teachers understanding of the differences between agricultural awareness and agricultural literacy in Iowa". Graduate Theses and Dissertations. Paper 13740.

[15] Nosiru Omobolanle M., 2010, "Microcredits and Agricultural Productivity in Ogun State", Nigeria, World Journal of Agricultural Sciences 6 (3): 290-296.

[16] Adinya I. B., Edet D., Nyienakuna M. G. and Ikpi G. U., 2011, "Estimation of efficiency constraints using cobbdouglass production function in snail (archachatina marginata) production by small farmers in cross river state", Nigeria, The Journal of Animal \& Plant Sciences, Page: 274-282.

[17] Orimoloye Ipoola Faleyimu, 2014, "Determinant of profitability in the wood carving industry in Oyo State, NIGERIA", Journal of Sustainable Development in Africa, Volume 16, No.1.

[18] Rehman Abdul and Khalid Mughal, 2013, "Impact of Technical Education on the Labor Productivity", International Journal of Economics, Finance and Management, vol. 2, NO. 7.

[19] Adebayo B. Aromolaran, 2004, "Female schooling, nonmarket productivity and labor market participation in Nigeria", Economic growth center, Yale University.

[20] Nsimire Balika A., 2012, «De l'exploitation agricole individuelle vers une agriculture entrepreneuriale en milieux ruraux du Sud-Kivu », colloque international, Débats entre monde académique, du développement et de la formation, Université de Toulouse II-le Mirail, France, du 22 au 24 mai.

[21] Fouzia Khanam, Zebun Nisa Khan, Knowledge: A Verb or a Noun in Education for Sustainable Development, International Journal of Elementary Education. Vol. 5, No. 6, 2016, pp. 58-62. doi: 10.11648/j.ijeedu.20160506.11.

[22] OKPACHU, ADOGWU. S., OKPACHU, OCHE. G., and OBIJESI, IFEOMA. K. (2014), The Impact Of Education On Agricultural Productivity Of Small Scale Rural Female Maize Farmers In Potiskum Local Government, Yobe State: A Panacea For Rural Economic Development In Nigeria, International Journal of Research In Agriculture and Food Sciences, Vol. 2, No.4, pp. 26-33. http://www.ijsk.org/ijrafs.html 